\title{
Green property development by Asian property companies
}

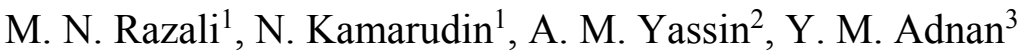 \\ \& Z. A. Baharom ${ }^{4}$ \\ ${ }^{1}$ Universiti Teknologi Malaysia, Malaysia \\ ${ }^{2}$ Universiti Tun Hussein Onn Malaysia, Malaysia \\ ${ }^{3}$ Universiti Malaya, Malaysia \\ ${ }^{4}$ Universiti Teknologi MARA, Malaysia
}

\begin{abstract}
The concept of sustainability has become increasingly essential in property development, especially in recent years. The purpose of this paper is to assess transparency levels in term of sustainability practices amongst listed property companies in Asian countries. The website and annual report of each company are assessed to determine the level of transparency in sustainable practices among property companies in Asia. Their sustainability strategies are then rigorously assessed by using a matrix scorecard, which takes into account several attributes concerning sustainability issues. Given the increasing significance of sustainability issues - especially in property development - amongst international property players, this paper enables more informed investment and decisionmaking regarding the implementation of sustainability in property portfolios. The results show that green or sustainable property development in Asian countries remains at a moderate level. There is still much room for improvement to increase the level of green elements in property development. Given the future significance of the Asian region, it is crucial to ensure green property development levels are sustained or increased in order to reduce environmental damage.
\end{abstract}

Keywords: transparency, sustainable, Asia, property companies. 


\section{Introduction}

The sustainability concept has taken on an increased importance in recent years, with awareness becoming more widespread in many disciplines. The Rio Summit in 2002 accelerated reduced waste and atmospheric emission pollutants in the world. The World Commission on Environment and Development (1987) (WCED) defines sustainability as development that meets the needs of the present without compromising the ability of future generations in order to meet their own needs. According to Papargyropoulou et al. [1], one aspect of development as a major contributor to global environmental degradation is the built environment. The built environment can contribute to environmental damage through activities such as energy consumption, solid waste management, defective designs, pollution, building materials, health hazards, construction processes and management, and water pollution. Studies that support this statement include Masnavi [2], Melchert [3] and Zimmermann et al. [4]. The possible definitions of sustainability vary widely and number more than 500, which leads to much confusion [5]. This is evidenced by a survey undertaken by Jones Lang La Salle (JLL), which reveals that the definition of sustainability continues to be debated by the real estate industry. Furthermore, the variety of topics included in survey participants' objectives, risk assessments, and disclosures, highlights the diverse views on the issue [6]. Sustainability is a broad, all-encompassing term, but the ability to assess the level of sustainability in a property is proving too elusive, with more than 600 environmental, social and economic assessment tools available [7].

As such, the concept of sustainable development was introduced to curb the problem of environmental impact from the development activities in the built environment. The term "sustainable development" was introduced following the 1987 publication of the WCED report. Its provision of a newer definition of sustainable development highlights critical interactions between employment, technology and environment in the process of development [8]. Since then, the need for greater environmental consideration in the context of sustainable development has been accepted in many governments, business, organizations and individuals [9]. Awareness of the need for sustainability has developed from an increasing global focus on the world's finite resources, excessive carbon dioxide emission levels, and the threatening consequences of global warming and climate change [10].

In theory, sustainable development is defined in terms of the pattern of structural changes in natural and manmade capital stock, inclusive of human capital and technological capabilities, which ensures the feasibility of at least a minimum socially desired rate of growth in the long run [11]. Sustainable development issues arise from environmental problems, resulting in pollution and damage to the earth. Through industrialization and globalization, the standard of living in the developed world has soared from bare subsistence to affluence, while the majority of people in the developing world remain subject to destitution [12]. With environmental concerns demanding more consideration in development, the sustainability concept has become a national issue. 
In recent years, property developers have become more aware about sustainability development and the need to be more environmentally responsible. Some potential benefits of implementing sustainable development practices are beginning to emerge, and industry actors are now more aware that they can hold more advantages than conventional approaches.

One of the most important issues regarding sustainability in property development concerns where the sustainable or green concept fits into an organization's culture, and how its use contributes to the bottom line. The suitability of the sustainable concept is important in representing the benefits of green and sustainable practices. Any new concept touted as "beneficial" usually requires time to actually deliver economic benefits, and reliance on these future benefits is often seen as a risk. This being the case, background knowledge about how to introduce the concept of sustainability in property development is crucial.

There has been a significant shift in commercial real estate markets worldwide towards incorporating sustainability in real estate portfolios [13]. For example, JLL came out with sustainability management in existing buildings' stock to concentrate on resource efficiency, mainly in relation to energy, water and waste [14]. Aspects of sustainability that are becoming more common throughout the commercial property value industry include recognizing the significance of environmental impacts on the sector - including climate change and potable water availability - and acknowledging that mitigation of these impacts must take a beyond-compliance perspective [15]. Accepting the link between property and social infrastructure, including the creation of a sense of belonging contributes to social amenity and the inherent relationship between a healthy workplace and increased workforce productivity. Acknowledging that business value includes, but is not limited to, economic value, can be created by a committed and comprehensive approach.

Sustainable property development has been introduced to reduce the impact of human activity on the development process in real estate. Recently the term "sustainability" has been correlated with "green" in reference to environmentally friendly buildings. This association was endorsed by Kats [16], who treated the two terms synonymously, and considered that green buildings use resources like energy, water, materials, and land more efficiently than buildings that are just built to code. However, Myers [17] stressed that in commercial real estate, it is not so much that a building is sustainable or green that matters, but rather the level of sustainability claimed. In some cases, existing buildings may comply with certain sustainability principles but are unrecognized because of rating system requirements and the lack of industry interest in existing stock [17]. However, the concept of building rehabilitation was introduced to facilitate the shift of existing buildings towards sustainability. The rehabilitation process involves restoration and new construction; the former returns the building to its original condition, whereas the latter modifies a building to meet current standards and codes [18]. In the long term, it aims to increase the sustainable elements in property. The promotion of sustainable practices in property development has seen the development of various low carbon technologies to improve environmental performance during implementation [19]. 
Asia has recently become a very dynamic region, attracting increased investment on the back of economic growth. The Asian region provides many opportunities for investment opportunities and a vast range of different investment criteria. Foreign investment in Asian countries has been increasingly significant in recent years and is promising to recover after the downturn of the Global Financial Crisis (GFC). Asian countries have shown remarkable economic performances in recent years, despite having been affected by several financial crises such as the aforementioned GFC and the Eurozone crisis. This trend is evident though increased foreign capital flows in all economic areas, and an improvement in the business environment in recent years.

Rapid economic growth in Asia has resulted in severe and irreversible environmental issues such as climate change, waste, pollution and atmospheric emissions. Sustainable development must therefore take place to balance economic growth and the environmental impact from development. Several countries in Asia have launched high-level policy initiatives and action plans to promote green growth, and the green economy [20]. Under the United Nations Economic and Social Commission for Asia and the Pacific (ESCAP), the policy drafted by ESCAP will be a guideline for Asian countries as a strategy for achieving sustainable development to pursue the dual objective of increased human well-being and environmental stewardship. In addition, the 2012 United Nations Conference on Environment and Development (Rio+20) saw many Asian countries commit to promote green economies and the concept of sustainable development [21].

For instance, the Philippines initiated green development by introducing the Philippine Agenda 21, based on the Rio summit. The agenda aims to promote harmony and achieves sustainability by emphasizing: (i) a scale of intervention that is primarily area-based, (ii) The national and global policy environment builds upon and supports area-based initiatives, integrated island development approaches where applicable and (iii) This recognizes the archipelagic character of the Philippines which includes many small island provinces and people and integrity of nature at the center of development initiatives. Similar with The Philippines, Thailand also very limited numbers of previous research pertaining on sustainable property development. Nevertheless, the Thai Government has met this challenge by promoting its Local Agenda 21 among local authorities, which establishes a vision and associated tasks to promote sustainable development at the local level [22]. A study by Chansam [23] revealed that the growth of $\mathrm{CO}_{2}$ emissions and energy consumption was higher than that of real GDP per capita in Thailand.

The promotion of sustainability has also taken place in one of the most powerful world economies: China. The Chinese Government is one of the first to introduce a national sustainable development program, known as Scientific Outlook and Development. However, based on the findings of a study by Zhang et al. [19], the implementation of green elements for property development projects face various barriers that do not apply to conventional buildings, such as higher costs for green appliance design and energy saving material at the design stage, and lengthy planning and approval processes for new green technologies. 
Furthermore, the use of recycled materials and a general unfamiliarity with green technologies results in delays in the design and construction process.

Although Hong Kong is governed under the auspices of the Chinese Government, research on sustainable development in this Special Administration Region is far more advanced in comparison to China. For example, the ESCAP [20] study on Hong Kong's model of sustainable development showed that its policies were inherited from those drafted during the British occupation. The first major government study to promote sustainable development in Hong Kong was the 'Study on Sustainable Development for the 21st Century', commissioned in 1997. Subsequently, the 'Hong Kong Declaration on Sustainable Development for Cities' was made during the Asia Pacific Leadership Forum in 2004.

Currently, research related to sustainable development and the green concept in Malaysia is growing. As sustainability becomes increasingly integrated in Malaysian property development, it has also gained attention at government level; in 2009, the Malaysian Government established the Ministry of Energy, Green Technology and Water in order to stimulate the green concept and sustainability in Malaysia. Prior to that, a National Policy on the Environment under the Ministry of Science, Technology and Environment was drafted to balance economic development with environmental needs, including the sustainable use of resources and environmental conservation. As a result, local researchers also sought to study this topic to assist government, policy makers and relevant players to apply sustainable elements in projects. For instance, Papargyropoulou et al. [1] studied the rise of sustainability services for the built environment in Malaysia. Their study found that the Malaysian built environment market offers a unique opportunity for businesses to invest and develop sustainability services whilst the market is relatively immature. They also determined that market growth in Malaysia will improve the environmental performance of buildings and other related infrastructure, delivering significant reductions in greenhouse gas emissions in the built environment sector. Other studies concentrated on Malaysia's sustainable issues, including Yusof and Jamaludin [25], who focused on green approaches among hotels and resorts in Malaysia. Isa et al. [26] explored green office building investment, and Abidin et al. [27] investigated the awareness and application of sustainable concepts by Malaysian developers. Increasing research linked to sustainability illustrates that awareness of these issues is growing, not only at government level but also amongst industry and other stakeholders.

Other Asian countries also have taken strict action to encourage the concept of sustainable development or green growth. South Korea has declared a low carbon green growth initiative as a national vision, Japan established policy principles to develop sound material cycles, and Cambodia has introduced a National Green Growth Roadmap. Vietnam has also launched a Green Growth Strategy to establish sustainability concepts around the country. Being a very dynamic region, it is important for Asia to advance its broader economy strategies in tandem with sustainable concepts. The large number of developing states that comprise most of Asia are well-placed to amend their national polices to meet sustainability standards and targets. Moreover, the concepts of sustainable development or green 
growth are also able to increase economic growth, and reduce negative environmental impacts for future generations. These concepts turn resource constraints and the climate crisis into economic growth opportunities through investment in economic growth and well-being, whilst using less resources and generating fewer emissions in the important domains of food production, transport and mobility, construction and housing, heavy industry, energy and water [28].

\section{Methodologies}

This paper examines a unique sample using the content analysis approach of the top 30 listed property companies' from five Asian countries: Malaysia, Indonesia, Thailand, Singapore and the Philippines. The top 30 listed property companies' annual reports were taken from the respective stock exchange of each company, and corporate websites were analyzed using several statistical techniques. All 120 listed property companies were selected for this survey based on a Datastream list as of December 2013. Apart from annual reports (which each publicly listed company is required to publish), company websites can also be a useful tool to determine the sustainability benchmark of property companies. With listed property companies representing the major actors in Malaysian property development, the survey of these companies represents the current status of sustainability in Asian property development.

The approach of this paper involved using company websites and desk research. According to South Coast Information and Library Services [29], "desk research" refers to the identification and analysis of information that has already been compiled and published in some form or another. In this sense, this type of information is regarded as secondary in nature. Using a similar research methodology by Newell and Manaf [30] on the Malaysian property sector, the attributes used to assess information transparency were modified by taking into account the local environment of the property business in Malaysia. Newell and Manaf used 14 attributes, divided into two major resources: websites and annual reports. Their case study was also limited to the top 30 companies based on market value in 2008 .

This study advances the elements of Newell and Manaf's research by introducing more sustainable attributes that corresponds to the latest environmental issues. Furthermore, it covers all listed property companies in Malaysia, so as to provide more accurate results in terms of sustainability levels among property companies in Malaysia. Assessment focused on projects operated by these companies as well as the sustainable elements they implemented.

This study encompasses 16 attributes to measure sustainability levels among property-listed companies in Asian countries which are; sustainable concept mentioned, sustainability in corporate social responsibility statement, environmental issues statement, special section on sustainability, policy on sustainability, sustainability award, green friendly projects, social sustainability, status of environmental management system, environmental system audit programme, conformance with environmental code standards, objectives targets relating to priority environmental issues, initiatives on sustainability practices, 
awareness programmes, sustainable strategies and financial report with integrated sustainability information. Newell and Manaf [30] identified sustainable property strategies at the corporate portfolio and individual property levels. They considered that while sustainability involves three dimensions of sustainability (being environmental, social and economic), examples largely focus on the environmental dimension. As such, for this research, environmental aspects will be included in the analysis assessment.

The matrix encompasses elements of sustainability and the green concept in property, including sustainable policy and sustainable awards. A section on sustainability and sustainable initiatives was included in the matrix in order to measure the extent of implementation of sustainable concepts among listed property companies in Asia. Other attributes which have a greater influence on environmental issues (such as green projects and environmental management systems), were used to examine advanced elements in sustainable whereas these attributes consider as innovation in sustainability concept.

All of the sustainability matrix attributes were assessed against each of the listed property companies by using equal weighting, resulting in a sustainability score out of 16. Top-down strategic focus on sustainability reporting was considered to be more effective than a bottom-up micro-practice approach, particularly given the higher priority of the top-down critical factors identified for successful energy management in Asia [31].

The data collected was based on visible information from company annual reports. In addition, a list of attributes pertaining to sustainable property development, referred to as a "sustainable property development strategy matrix", was developed. Each annual report was then reviewed and a score was given to develop an index. Using the matrix, the listed property companies were evaluated in terms of their sustainable property development elements. Finally, a score was given for each variable that the companies implemented in their property projects.

This paper also seeks to analyze the sustainable property development of Asian listed property companies to evaluate whether these companies consider the sustainability concept as a necessity in property projects.

\section{Results and discussions}

A matrix table was used to assess the sustainability property development concept among listed property companies in Asia. Table 1 presents the score for top 30 property companies for all attributes in the matrix. The findings indicate the score for each listed property company according to each matrix attribute. The results clearly show that a majority of companies shared equal ranking due to having the same score in the matrix. However, for those ranked in the top four, the scores for each company differ, thus indicating that only a few companies are able to fulfill sustainable property development criteria. The results also indicate that there are no listed property companies in Asia capable of achieving a full score according to the matrix. This suggests there is still room for improvement for these companies in applying the sustainable property development concept in real estate projects. 
The findings revealed that eight companies - namely Mah Sing Group (Malaysia), Global Logistic (Singapore), Capitaland (Singapore), City Developments (Singapore), Capitalmalls Asia (Singapore), Capitalmalls Trust (Singapore), UOL Group (Singapore) and Ayala Land (Philippines) - almost achieved a full score in the matrix. The matrix also revealed that amongst the highest scoring companies, Singaporean companies dominated the top 10 places. This indicates that many Singaporean property companies apply sustainable or green practices in their property development projects. Singapore is followed by Thai companies (Central Patana and BTS Group) and Malaysian companies (Mah Sing Group). Note that due to the language barrier, the findings excluded companies from Hong Kong and China, as most of their reports are in their native language. Some Thai companies were also excluded from the analysis, where their reports were drafted exclusively in Thai.

The mean score for the property development index matrix is 3.3 , which is very low. This signifies a low implementation of sustainable development for property projects in Asia.

Overall, the matrix findings showed that the majority of listed property companies that were able to score points in the sustainable property development matrix are Singaporean, followed by Malaysian and Thai companies.

Table 1: Sustainable property development index matrix ranking.

\begin{tabular}{|c|c|c|}
\hline No. & Company & Point \\
\hline \multirow[t]{8}{*}{1.} & Mah Sing Group & 15 \\
\hline & Global Logistic & 15 \\
\hline & Capitaland & 15 \\
\hline & City Development & 15 \\
\hline & Capitalmall Asia & 15 \\
\hline & Capitalmall Trust & 15 \\
\hline & UOL Group & 15 \\
\hline & Ayala Land & 15 \\
\hline \multirow[t]{3}{*}{9.} & Ascendas & 14 \\
\hline & Central Pattana & 14 \\
\hline & BTS Group & 14 \\
\hline \multirow[t]{2}{*}{12.} & Encorp Berhad & 13 \\
\hline & Cebu Holdings & 13 \\
\hline \multirow[t]{8}{*}{14.} & Sunway Group & 12 \\
\hline & SM Prime & 12 \\
\hline & Ciputra Development & 12 \\
\hline & Ciputra Property & 12 \\
\hline & Metropolitan land & 12 \\
\hline & Bakrieland Dev. & 12 \\
\hline & LPN Development & 12 \\
\hline & Pruksa & 12 \\
\hline
\end{tabular}

Table 2 presents sustainable property development rankings based on the score for each attribute. The findings determine which attributes are the most implemented by listed property companies in Asia. As mentioned above, these 
attributes provide an overview of factors that are believed to be sustainable indicators for Asian listed property companies. Other relevant factors beyond the identified attributes inevitably exist and should be considered, however the attributes used in this study are identified as pillars, based on various literature reviews.

The results revealed that only three attributes ("sustainability concept mentioned", "sustainability in corporate social responsibility statement" and "initiatives on sustainability practices") managed to achieve a score that exceeded half of the total score. This suggests that the majority of Asian listed property companies are only able to implement, on average, three major attributes in the sustainable property development matrix. In turn, this signifies a lack of recognition of the sustainability concept among listed property companies in their projects, as well as within their organizations. Furthermore, no single attribute acquired a $100 \%$ score by listed property companies in Asia. Additionally, five attributes - namely "status of environmental management system", "objectives or targets relating to priority environmental issues", "special section on sustainability", "environmental system audit program" and "financial report with integrated sustainability information" - were implemented for property development projects in less than ten companies, representing only $0.13 \%$ of the total listed property companies in Asia.

Table 2: Sustainable development matrix attributes ranking.

\begin{tabular}{|l|l|l|}
\hline Ranking & Attributes & Score \\
\hline 1 & Sustainability concept mentioned & 64 \\
\hline 2 & Initiatives on sustainability practice & 56 \\
\hline 3 & Sustainability in corporate social responsibility statement & 55 \\
\hline 4 & Awareness programs & 46 \\
\hline 5 & Social sustainability & 43 \\
\hline 6 & Objectives or target relating to priority environmental issues & 43 \\
\hline 7 & Policy on sustainability & 42 \\
\hline 8 & Conformance with environmental codes on standards & 40 \\
\hline 9 & Status of environmental management system & 40 \\
\hline 10 & Environmental system audit program & 37 \\
\hline 11 & Environmental issues statement & 34 \\
\hline 12 & Special section on sustainability & 33 \\
\hline 13 & Green/environmentally friendly projects & 22 \\
\hline 14 & Sustainable strategies & 18 \\
\hline 15 & Sustainability award & 16 \\
\hline 16 & Financial report with integrated sustainability information & 0 \\
\hline
\end{tabular}

Overall, the sustainability concept in property development by listed property companies was widely promoted throughout several mediums, such as mentioning "sustainability concept" in projects, as well as through corporate social responsibility statements. Attributes such as "status of environmental management 
system", "special section on sustainability", "environmental system audit program" and "financial report with integrated sustainability information" attracted the least attention from listed property companies. These attributes are believed to represent the most advanced stage in sustainability in real estate. Based on the results, therefore, one could conclude that the level of sustainability awareness among listed property companies is still quite low.

\section{Conclusions}

This paper investigates the sustainability practices amongst listed property companies in Asia. All 159 listed property companies were included in this study to examine the level of sustainability in their property projects. Sustainability levels were examined by using a sustainability property development matrix. The matrix encompasses several attributes that were designed based on several literature surveys and similar previous research. This sustainability index was then compared to the ranking of listed property companies, based on market value. Overall, it was found that the sustainability level among listed property companies in Asia is at a satisfactory level and is poised to experience rapid changes. Several property development projects in Asia have been identified as green or sustainable. Property companies launched these projects either to participate in a governmentdriven sustainability campaign, or as part of their broader marketing strategies to attract buyers.

With an average of $26 \%$ of listed property companies displaying sustainability attributes, it can be concluded that only a few listed property companies have widely implemented sustainability elements. The awareness of sustainability among listed property companies can be categorized at a low level, although this is increasing. This can be seen from the several projects that attempt to apply sustainability elements. This paper also investigates the definition of sustainability, especially for bigger companies in terms of market value.

Top property companies by market value ranking and those ranked highly in the sustainability property development index were also tested to analyze the rank correlation between these two indexes. The findings revealed that there is no correlation between the two categories. This indicates that the top-listed property companies in Asia have not necessarily made enough effort to promote the sustainability concept in their projects to fulfill their sustainability policies.

The findings on rank correlation analysis contradicts Khadaroo's findings [32], which mentioned establish a website is influenced by several factors such as company size and expected number of users. Interestingly, some small companies in terms of market value have scored highly for sustainability attributes. All stakeholders need to play their role to ensure the success of the sustainability development agenda. Encouraging factors as listed by Abidin et al. [27], include the introduction of a Green Building Index (GBI) rating system, improved awareness and knowledge dissemination, government support, the potential support of local suppliers and manufacturers, increased public awareness, and the effect of competitive advantage. Listed property companies can play a major role to promote sustainable development, as property is essential for people and nations alike. 


\section{References}

[1] Papargyropoulou, E, Padfield, R., Harrison, O. and Preece, C., The rise of sustainability services for the built environment in Malaysia, Sustainable Cities and Society, 5: 44-51, 2012.

[2] Masnavi, M.R., Measuring urban sustainability: Developing a conceptual framework for bridging the gap between theoretical levels and the operational levels. International Journal of Environmental Research, 1(2): 188-197, 2007.

[3] Melchert, L., The Dutch sustainable building policy: A model for developing countries. Building and Environment, 42(2): 893-901, 2005.

[4] Zimmermann, M., Authaus, H.J. and Haas, A., Benchmarks for sustainable construction- A contribution to develop a standard. Energy and Buildings. 37(11): 1147-1156, 2005.

[5] Phillips, C., Sustainable place: A place of sustainable development, Wiley Academic: British Isle, 1989.

[6] Jones Lang LaSalle, Resilient Cities and Urban Futures: Global Sustainability Perspective. London. JLL, 2005.

[7] Dixon, T., Colantonio, A., Shiers, D., Reed, R., Wilkinson, S. and Gallimore, P., A green professional? A global survey of RICS members and their engagement with the sustainability agenda. Journal of Property Investment and Finance, 24: 460-481, 2008.

[8] Karshenas, M., Environment, Technology and Employment: Towards a New Definition of Sustainable Development. Development and Change, 25 (4): 723-756, 1994.

[9] Das Gandhi, N.M., Selladurai, V. and Santhi, P., Unsustainable development to sustainable development: a conceptual model. International Journal of Management of Environmental Quality, 17(6): 2006.

[10] Myers, G.W., Sustainable management of real estate: Is it really sustainability. Journal of Sustainable Real Estate, 4: 178-197, 2012.

[11] Karshenas, M., Environment, Technology and Employment: Towards a New Definition of Sustainable Development, Development and Change, 25(4): 723-756, 1994.

[12] Mebraru, D., Sustainability and sustainable development: Historical and conceptual review. Environmental Impact Assessment Review, pp. 493-450, 1998.

[13] Defancesco, A.J. and Levy, D. The impact of sustainability on the investment environment. Journal of European Real Estate Research, 1: 72-87, 2008.

[14] JLL (2006). Assessing the value of sustainability. Jones Lang LaSalle, Sydney.

[15] Shub, G., Beardsley, B., Donnadieu, H., Kramer, K., Kumar, M., Maguire, A., Morel, P. and Tang, T., Global asset management 2013: Capitalizing on the recovery, Online:

https://www.bcgperspectives.com/content/articles/financial_institutions_gl obal_asset_management_2013_capitalizing_recovery/. 
[16] Kats, Green Building Costs and Financial Benefits, Massachusetts Technology Collaborative, USA, 2003.

[17] Myers, G.W., Value sustainability: A challenge for the profession. Australia and New Zealand Property Journal, 2011: 3, 2011.

[18] Bullen, P.A., Adaptive reuse and sustainability of commercial buildings. Facilities. Vol. 25, No. 1/2: 20-31, 2007.

[19] Zhang, X., Platten, A. and Shen, L., Green property development practice in China: Costs and barriers. Building and Environment, 46: 2153-2160, 2011.

[20] United Nations Economic and Social Commission for Asia and the Pacific, Green Growth Indicator: A practical approach for Asia and the Pacific. Bangkok: ESCAP, 2013.

[21] Environment and Development Division United Nations Building (ESCAP), United Nations: Thailand, 2013.

[22] Nakaguchi, T., Zizokukano na hattenseisaku to Rokaru Ajenda 21 no genjo to kadai [Policies for sus-tainable development and the present situation and challenge for Local Agenda 21]. In K. Kawasaki, T. Nakaguchi, \& K. Ueta (Eds.), Kankyo management to machi zukuri: Sanka to komyuniti gabanansu (pp. 28-39). Kyoto, Japan: Gakugei Shuppan-sha, 2004.

[23] Chansam, S., Assessing the sustainable development of Thailand. Procedia Environmental Science, 17: 6110619, 2013.

[24] Lawrence, W.C.L., Kwong, W.C., Daniel, C.W.H. and Lorne, F.T., A Hong Kong model of sustainable development, Property Management, 24(3): 251-271, 2006.

[25] Yusof, Z.B. and Jamaludin, M., Green approaches of Malaysian Green Hotels and Resorts, Procedia Social and Behavioral Sciences, 85: 421-431, 2013.

[26] Isa, M., Rahman, M.M.G.M., Sipan, I. and Ting, K.H., Factors affecting green office building investment in Malaysia, Procedia Social and Behavioral Science, 105: 138-148, 2013.

[27] Abidin, N.Z., Yusof, N. and Awang, Y.H., A foresight into green housing industry in Malaysia, World Academy of Science, Engineering and Technology, 67: 440-448, 2012.

[28] United Nations Human Settlements Programme, Planning sustainable cities: Global report on human settlement. London: Earthscan, 2009.

[29] South Coast Information and Library Services, University Bournemouth, Marketing Desk Research, available at: www.zmfkht.hu/dl_sp.php?id1/ 46\&f1/4MarkDeskResearch.pdf, 1995. (Accessed April 21, 2013.)

[30] Newell, G. and Manaf, Z., The significance of sustainability practices by the Malaysian property sector, Local Economy 23(3): 152-167, 2008.

[31] Asia Business Council, Building Energy Efficiency: Why green buildings are key to Asia's future (Hong Kong: ABC), 2007.

[32] Razali, M.N. and Adnan, Y.M. Transparency in Malaysian property companies. Property Management, 30(5): 398-415, 2012. 